\title{
Slavic-Albanian Language Contact: Lexicon
}

\author{
Matthew C. Curtis \\ The Ohio State University, 400 Hagerty Hall, 1775 College Road, \\ Columbus, Ohio 43210, (614)292-6733,mirefare@gmail.com
}

SCN V/2 [2012], 5-20

\begin{abstract}
V prispevku so obravnavane zgodovinske povezave med slovanskimi jeziki in albanščino, in sicer na podlagi treh pristopov $\mathrm{k}$ preučevanju besednih izposojenk: raziskave Fransa van Coetsema (1988/2000) o izposojenkah in njihovemu uveljavljanju, lestvice izposojenk, ki sta jo utemeljila Thomason in Kaufman (1988), ter raziskave Friedmana in Josepha (2014) o izposojenkah ERIC (Essentially Rooted in Communication 'pretežno izvirajoče iz komunikacije'). Med preučevanjem geografske in semantične širitve besednih izposojenk se je izkazalo, da so imeli slovanski jeziki večji geografski vpliv in so prispevali več izposojenk, medtem ko je albanski jezik prispeval predvsem besedje sorodstvenih vezi ter drugih kategorij, ki so bile izposojene kot posledica intenzivnega in dolgotrajnega jezikovnega stika. Ta stik predpostavlja bogato in raznoliko povezanost, ki se je razvila pod vplivom različnih okoliščin, tudi v obdobju, ko so jeziki mirno soobstajali.
\end{abstract}

This paper examines the nature of Slavic and Albanian historical interactions on the basis of three approaches to lexical borrowings: Frans van Coetsem's (1988/2000) concepts of borrowing and imposition, scales of borrowability as found in Thomason and Kaufman (1988), and Friedman and Joseph's (2014) notion of ERIC loans (Essentially Rooted in Communication). By examining the geographic and semantic spread of vocabulary borrowed, Slavic appears to have had a greater influence in terms of geography and quantity of borrowings, while Albanian has also contributed words for kin and other categories likely borrowed under intense or prolonged contact, suggesting rich and diverse interactions that have occurred under a variety of circumstances, including times of peaceful coexistence.

Ključne besede: slovanski jeziki, albanščina, jezikovni stik, izposojenke, besedje

Key Words: Slavic, Albanian, Language Contact, Borrowings, Lexicon 


\section{Introduction}

While the historical relations of Slavs and Albanians are frequently implicated in political rhetoric and national policy (Vermeer 1992), this brief article attempts an objective examination of linguistic evidence for contact between Slavic and Albanian. ${ }^{1}$ Of necessity, only part of the evidence is examined here-the lexicon-but shared phonological, morphosyntactic, and semantic features also establish the influence of contact between Slavic and Albanian (Curtis 2012; Stanišić 1995; Blaku 1989/2010). Two historical linguistic facts make it difficult to determine whether given words have been borrowed between Slavic and Albanian: 1) their common descent from Indo-European (Hamp 1970) and 2) their participation in the Balkan Sprachbund. As far as the socio-political history is concerned, since the Slavs' migrations to the Balkans in the $6^{\text {th }}$ century Albanians and Slavs have been subject to a variety of ruling groups. These include third-party rulers like the Byzantine and Ottoman Empires; Slavic empires, kingdoms, federations, and nation-states; and Albanian kingdoms and nation-states. Given the long-standing contact and the various political arrangements that the populations lived in, changes in the language are to be expected. As argued below, the vocabulary shared by Albanian and Slavic dialects broadly reflects these periods of evolving cultural interaction.

\section{Theoretical Approaches to Vocabulary Borrowings in Language Contact}

Three approaches to borrowing vocabulary show some of the ways in which Slavic-Albanian borrowings reflect the sociolinguistic setting of this contact: Imposition vs. Borrowing, Scales of Borrowing, and the idea of ERIC loans. While these approaches differ theoretically, they each seek to establish the sociolinguistic setting in which language contact occurs.

The first approach is Frans van Coetsem's (1988/2000) distinction between two transfer types in language contact: borrowing and imposition. Borrowing is the process whereby speakers incorporate material (usually words) into their cognitively dominant language from another language they are familiar with. Examples include English déjà vu, French le bigmac, and Russian рояль. Imposition, by contrast, is a speaker's transfer of material (usually structure) from their cognitively-dominant language into a second language (L2). Examples include the "accent" language learners carry over from the phonology of their

${ }^{1}$ This paper is largely based on a presentation at the $31^{\text {st }}$ annual Slavic Forum at the University of Chicago, May 2011. Thanks to the many helpful participants there, as well as to those who helped shape that presentation in the Slavic Linguistics Forum at The Ohio State University and subsequent reviewers of drafts for this article. Though indebted to many for the improvements on this work, I remain solely responsible for the work represented here. 
first language (L1). These effects are described in other branches of linguistics by the terms transfer (SLA) or substrate influence (historical-comparative). Van Coetsem's language-contact distinctions offer a possible way of discerning social relations of populations in a language-contact situation. In general, speakers are cognitively dominant in their L1, even if it is not a socially dominant language. ${ }^{2}$ Cognitively dominant languages are less likely to be the source of vocabulary borrowing but are more likely the cause of structural changes in an L2 speakers come into contact with. So, for example, a dialect with phonological and morphosyntactic divergences has likely undergone imposition by a population assimilated into that language community. A speaker's dominant language is not always her L1, and in the process of L2 learning, L2 features can also influence L1. This process, called 'reverse interference' by Friedman and Joseph (2014), seems to be behind many of the structural convergences found in the Balkan Sprachbund. This also makes analyses like the one above problematic. Still, van Coetsem's distinctions allow the tentative prediction that the source languages of borrowed lexicon are not likely dominant cognitively, whereas languages providing phonological and morphosyntactic structure typically are.

A second approach is the idea that certain parts of vocabulary are more likely to be borrowed than others. This is the basis for many analyses of borrowing in individual case studies and is also inherent in cross-linguistic studies and theoretical formulations of language-contact such as the scale of borrowability put forward by Thomason and Kaufman (1988: 74-76). In their approach, they correlate linguistic effects of borrowing with the intensity of contact between cultures involved. This is represented in their "Scale of Borrowing" given in Figure 1.

\begin{tabular}{|c|c|c|}
\hline Casual Contact & Category 1 : & Content words \\
\hline & Category 2: & Function words, minor phonological features \\
\hline & Category 3 : & Adpositions, derivational suffixes, phonemes \\
\hline$\downarrow$ & Category 4: & $\begin{array}{l}\text { Word order, distinctive features in phonology, } \\
\text { inflectional morphology }\end{array}$ \\
\hline Intense Contact & Category 5: & $\begin{array}{l}\text { Significant typological disruption, phonetic } \\
\text { changes }\end{array}$ \\
\hline
\end{tabular}

Figure 1. Thomason and Kaufman's (1988) borrowing scale

The final approach is that of Friedman and Joseph (2014) who add a distinction to the tradition found for example in Bloomfield (1933) who distinguishes between cultural and intimate loans, to describing individual borrowings on the basis of their semantic or pragmatic properties in the context of whether given words would come from repeated, regular contact between languages,

\footnotetext{
${ }^{2}$ Van Coetsem is very careful to emphasize that the dominance is a cognitive distinction, and not a social dominance; minority languages are examples of languages not being dominant socially, but for their speakers they are dominant cognitively.
} 
what have been called "ERIC loans", i.e. loans that are "Essentially Rooted in Conversation", a term first introduced by Joseph 2010 and elaborated on in some detail in Friedman and Joseph (2013; 2014). These include kinship terms, numerals, and words with grammatical value such as pronouns, prepositions, complementizers, discourse particles, etc. Such borrowings indicate close cultural connections, as they are unlikely to be transmitted in any other way than in routine conversation with speakers of the source language.

Table 1. ERIC loans in Balkan Languages. (Examples from Friedman and Joseph 2014)

\begin{tabular}{|c|c|c|c|c|c|}
\hline & $\begin{array}{c}\text { Kinship } \\
\text { terms }\end{array}$ & \multicolumn{3}{|c|}{$\begin{array}{c}\text { Words w/ } \\
\text { grammatical value }\end{array}$} & $\begin{array}{c}\text { Set } \\
\text { expressions }\end{array}$ \\
\hline Turkish & Baba & hiç & karş1 & - & anadan babadan \\
\hline Macedonian & Баба & ич & карши & - & $?$ \\
\hline Albanian & Ваba & hiç & karshi & mbase & dembabaden \\
\hline Greek & $\mu \pi \alpha \mu \pi \alpha$ & - & - & $\mu \eta \pi \omega \varsigma$ & anadam babadam \\
\hline Aromanian & baba & hiç⿳̆ & carş1 & - & $?$ \\
\hline Gloss & 'father' & $\begin{array}{c}\text { 'nothing' } \\
\text { (pron.) }\end{array}$ & $\begin{array}{c}\text { 'opposite, } \\
\text { against' } \\
\text { (prep.) }\end{array}$ & $\begin{array}{c}\text { 'perhaps' } \\
\text { (comp.) }\end{array}$ & $\begin{array}{c}\text { 'in the distant past' } \\
\text { lit. 'from the } \\
\text { mother, from the } \\
\text { father' }\end{array}$ \\
\hline
\end{tabular}

\section{Data}

The goal of this analysis is not merely to discuss different cultural elements represented in borrowed vocabulary; it is rather, to describe the sociolinguistic context in which the vocabulary is transmitted across the languages involved. To this end, I investigate words borrowed from Slavic languages into Albanian and the somewhat smaller number of lexical items attested in Macedonian, Serbian, and Montenegrin dialects that have likely come from Albanian. First, I focus on the cultural information transmitted in borrowings from both directions in Slavic-Albanian borrowings: Slavic into Albanian, then Albanian into Slavic, after which, I briefly analyze the place and time of borrowings in the language contact situation.

\subsection{General remarks on Slavic-Albanian borrowings}

In general, it may be said that the borrowings from Slavic to Albanian are much more numerous and wide-ranging than borrowings from Albanian to Slavic, in terms of quantity of and geographic spread. All in all, Slavic languages have contributed around 1000 words to Albanian (Svane 1992; Ylli 1997). Accord- 
ing to Svane's collection of loanwords, most of these are nouns (754) and verbs (169), while adjectives (65) and other words (9) are also present. Words borrowed into Slavic dialects from Albanian number around 550, again with nouns (402) making up the majority of those borrowings. Verbs (63) and adjectives (40) comprise the next largest groups of borrowings, with other words making up a smaller amount (37). Figure 2, below, compares the number and parts of speech represented in the borrowings.

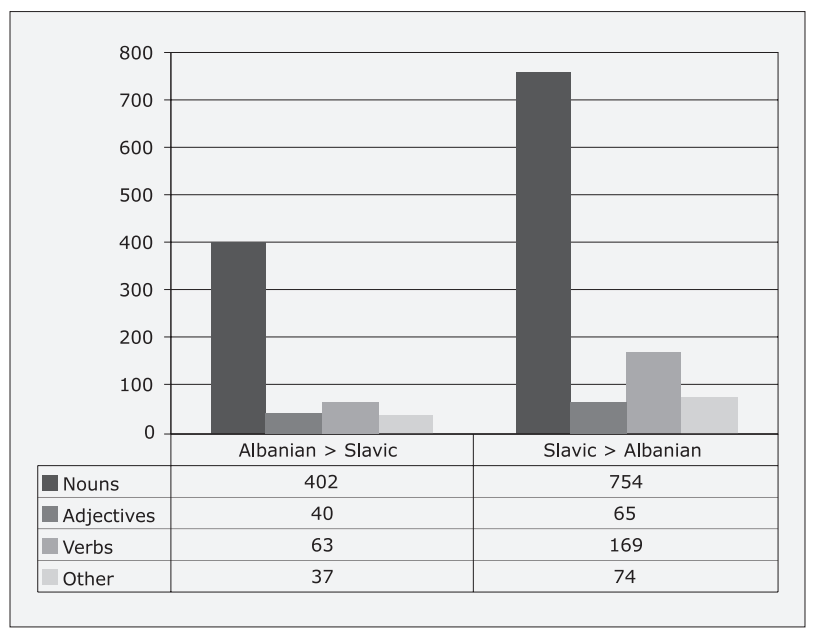

Figure 2. Number of Borrowings by Grammatical Category

While borrowings of Slavic into Albanian certainly have been more prolific in Albanian, Albanian borrowings into Slavic have also had an impact that has not been generally acknowledged. In many of these, Albanian is often not the original source for borrowings, but as Albanian has borrowed from many other languages throughout its history, it is not surprising that words originating from Greek and Latin, etc. should be found in this corpus of loanwords. These include words borrowed from Greek, Latin, Turkish, even Slavic itself: Mk. ${ }^{3}$ preš 'leek' Alb. presh ${ }^{4}<\mathrm{Gk} . \pi \rho \alpha \sigma o v$, Mne. šočnija 'society', Alb. (Geg)

\footnotetext{
${ }^{3}$ As explained below, almost all loanwords from Albanian into Slavic dialects are limited to dialects in contact with Albanian. The abbreviations for these dialects follows the labels used by Hoxha (2001). Abbreviations used here are: $M k$. for dialects in Macedonia, Mne.-Montenegro, Srb.-Serbia, Blg.-Bulgaria, and Kos.-Kosovo.

${ }^{4}$ Thanks to an anonymous reviewer who pointed out further dialectal variation in Albanian for the term 'leek'. In addition to the form given above, presh, generally taken to be from the Anc. Gk. cited above, there is also the form pras (in Turjakë, Kosovo) which is likely a borrowing from either Mod. Gk. $\pi \rho \alpha \dot{\sigma o v}$ (or from Slavic cf. OCS npacb according to Svane (1992: 107) and the form purr (in Cernicë, Kosovo) likely borrowed from Romance, cf. Latin porrum. The variety of forms for this term may be due to reborrowing in exogamous marriages as this is a cooking term that the wife could bring into the language community (see Thumb 1910: 19).
} 
shoq-nia ${ }^{5}<$ Lat. socius 'friend', porosija 'order, request', Alb. porosia, porositi $<$ CSl. po-ročiti (cf. Srb. poručiti 'to order') and Turkish (gurdževar 'precious stone', Alb. gurxhevair (Alb. gur 'stone' + Turk. cevahir 'jewel').

\subsection{Cultural Information Transmitted in Borrowings}

One advantage of studying vocabulary in language contact situations is that it gives an indication of what concepts may have characterized the source language from the perspective of those speakers who have borrowed from it; the same can rarely be said of phonology or morphosyntax. From an analysis of the semantic categories of these borrowings, the vocabulary borrowed from Slavic into Albanian differs greatly from borrowings from Albanian into Slavic, although certain similarities exist. Each of the communities in contact has contributed to the other's lexical repertoire and has also been reciprocally affected by these interactions. Tables 2 and 3, below, give additional information about semantic categories represented in Slavic $\rightarrow$ Albanian borrowings and Albanian $\rightarrow$ Slavic borrowings respectively.

Table 2. Borrowings from Slavic into Albanian (based on Svane 1992)

\begin{tabular}{|c|c|c|c|c|c|}
\hline Category & Items & Sample & Slavic & Albanian & Alternative \\
\hline Agriculture & 90 & $\begin{array}{c}\text { plow } \\
\text { (modern iron) }\end{array}$ & plug (Sr, Mk) & plug, pllug & parmendë \\
\hline $\begin{array}{l}\text { Material } \\
\text { Culture }\end{array}$ & 193 & $\begin{array}{l}\text { furnishings, } \\
\text { equipment }\end{array}$ & $\begin{array}{l}\text { oruđe }(\mathrm{Sr}) \text {, orudie } \\
(\mathrm{Mk}) \text {, orъdie }(\mathrm{Bg})\end{array}$ & orendi & mobilje \\
\hline Plants & 93 & cucumber & $\begin{array}{l}\text { krastavac (Sr), } \\
\text { krastavica (Bg) }\end{array}$ & kastravec & $\begin{array}{l}\text { trangull, } \\
\text { sallator }\end{array}$ \\
\hline Animals & 120 & donkey & $\begin{array}{c}\text { magarac }(\mathrm{Sr}), \\
\text { magare }(\mathrm{Bg})\end{array}$ & $\begin{array}{l}\text { magare, } \\
\text { magarc }\end{array}$ & gomar \\
\hline Environment & 75 & $\begin{array}{l}\text { hill, bank, } \\
\text { coast, rim }\end{array}$ & breg (Sr, Mk) & breg & $\begin{array}{l}\text { kodrinë, } \\
\text { mal, }\end{array}$ \\
\hline Human Body & 47 & bone & $\begin{array}{l}\text { kost, dim. kosta } \\
\text { (S. Sl.) }\end{array}$ & kockë & asht \\
\hline
\end{tabular}

${ }^{5}$ Cf. std. Albanian shoqëria. Geg -nia, standard -ëria, is a suffix used to form abstract nouns of the condition of the root: shoqnia, shoqëria 'society, companionship', shok 'friend, companion'; burrnia 'manliness', burr 'man' 
Table 3. Borrowings from Albanian into Slavic (based on Hoxha 2001)

\begin{tabular}{|c|c|c|c|c|c|}
\hline Category & Items $^{6}$ & Sample & Slavic & Albanian & Alternative \\
\hline Agriculture & 17 & field & fuša (Mne) & fushë & pole \\
\hline $\begin{array}{l}\text { Material } \\
\text { Culture }\end{array}$ & 55 & $\begin{array}{l}\text { sleeveless } \\
\text { woolen } \\
\text { smock }\end{array}$ & džupuleta (Mne) & xhubletë & \\
\hline Animals & 30 & $\begin{array}{l}\text { white } \\
\text { spotted } \\
\text { animal }\end{array}$ & $\begin{array}{c}\text { barzav (Mk), } \\
\text { barla (Kos) }\end{array}$ & $\begin{array}{l}\text { bardhosh, } \\
\text { bardhok }\end{array}$ & belica \\
\hline $\begin{array}{l}\text { Human } \\
\text { Body }\end{array}$ & 20 & $\begin{array}{l}\text { wound, } \\
\text { bruise }\end{array}$ & pljaga (Mk) & plagë & rana \\
\hline $\begin{array}{c}\text { Social } \\
\text { Organization }\end{array}$ & 59 & son, boy & bir (Kos, Mk) & bir & $\sin$ \\
\hline Verbs & 48 & (to) error & gabonjam (Mne) & $\begin{array}{l}\text { gabohem, } \\
\text { Geg } \\
\text { gabonjam }\end{array}$ & grešiti (se) \\
\hline Adjectives & 50 & $\begin{array}{l}\text { dead, } \\
\text { lifeless }\end{array}$ & cofnat (Mk) & i/e cofët & umren \\
\hline Other Words & 36 & $\begin{array}{l}\text { that } \\
\text { (comple- } \\
\text { mentizer) }\end{array}$ & se (Kos) & se & da, što \\
\hline
\end{tabular}

Borrowings from Slavic into Albanian are characterized by a preponderance of terms for farming, cultural objects, and nature. Many common farming terms, such as plug, '(modern iron) plow', oborr 'yard' are included in these borrowings. Svane (1992), however, warns against the interpretation that Slavs introduced farming to Albanians, as a native term for 'plow' exists, parmendë, which refers specifically to wooden plows; thus, the Slavs more likely contributed to technological advances in farming, rather than introducing it as a completely new way of life. In addition to farming objects, Slavic terms for other cultural objects are plentiful. Examples include orendi 'furniture, equipment', lopatë 'shovel', and opingë 'sandal, traditional shoe'. The greatest number of substantive lexical contributions, however, comes in plant and animal names, geographical terms, and other natural phenomena such as ljubiçicë 'violet', kastravec 'cucumber', sokol 'falcon', and flladë 'breeze'. In comparison with these, borrowings concerning literacy, religion, and other marks of learned society are much more rare (around 11 altogether), suggesting that Slavic-

${ }^{6}$ Hoxha (2001) gives partial listings of borrowings he considers in divisions of semantic fields. This table combines his fields, where possible, to correspond to categories used by Svane (1992) to facilitate comparison. These numbers should be taken only as a representation of how many there are relative to other categories. In addition to the items enumerated here, he gives several more when discussing the parts of speech. 
Albanian interactions happened mostly in non-literate, agrarian communities. Furthermore, due to the large number of alternative lexemes for concepts of Slavic loanwords, Slavic cultures did not necessarily introduce novel concepts; rather they added nuances of meanings to items or concepts already known to Albanians (Svane 1992: 281-282).

Borrowings from Albanian into Slavic are much smaller in number, however they have made some important contributions in Slavic dialects. As with Slavic $\rightarrow$ Albanian borrowings, these did not necessarily introduce novel ideas, but rather added terms to several semantic areas such as heroic virtues and kinship relations. While Çabej (1962/2008), Murati (2007), and others have described the addition of Albanian pastoral terms to Slavic dialects such as barzo 'white animal, (particularly sheep)' (compare Alb. bardhë 'white goat or sheep; white'), ${ }^{7}$ Hoxha (2001) and Stanišić (1995) also point to ethical qualities incorporated into Slavic dialects in Montenegro, Kosovo, Southern Serbia ${ }^{8}$, and Macedonia, such as besa 'word of honor, true' (Mne, Kos, S. Srb, Mk), burnija 'manliness, courage' (Mne, Mk), tremnija 'brave, heroic' (Mne, Kos), vulnet 'will' (Mne), compared to the northern Albanian terms besa, burrnia, trimnia, and vullnet, with similar meanings in each language. Kin terms are more controversial, because many are just as likely Slavic $\rightarrow$ Albanian borrowings or separate innovations as nursery terms in each language. Some of the more sure Albanian $\rightarrow$ Slavic kinship borrowings include bija 'daughter' (Mne, Kos, Mk), binjak 'twin' (Mk), bir 'son, boy' (Mne, Kos, Mk), nipeša 'neice' (Mne), nipče 'nephew' (S. Srb), and fis 'family, kin' (Mne, Kos). Furthermore, calques of Albanian kinship terms are found in Montenegro tribal organizations as well, such as bratstvo 'clan, (lit. brother-hood)', compared to Alb. vllaznija, both of which are composed of the root BROTHER + collective suffix. ${ }^{9}$ Examples of disputed kinship terms are baba 'grandmother', baca 'uncle', deda 'grandfather.' Regardless of how these last terms are judged, it is apparent that Slavic dialects in contact with Albanian have incorporated certain terms relating to the kinship and ethics of the heroic culture in Albanian and Slavic communities (Curtis 2007).

${ }^{7}$ The 1980 dictionary Fjalor $i$ gjuhës së sotme shqipe (Dictionary of the Contemporary Albanian Language) lists 'white goat or sheep' (dhi e dele e bardhë) as its first definition (1980: 101), while the adjectival is listed first in some other dictionaries, such as Thomaj et al (2006: 73) and Newmark (1998: 48).

${ }^{8}$ By "Southern Serbia", I mean the areas in Southern Serbia including the communities of Preševo, Medveđa, etc. that have had historical contact with Albanian populations or that continue to have contact with Albanian.

${ }^{9}$ Thanks once again to Victor Friedman for reminding me of this important point of language convergence, which, although it does not fit into the same category of other borrowings discussed here, as far as the form of the word is concerned, points to an important aspect of shared traditional culture and familial organization. 


\subsection{Place of Borrowings}

The geographical distribution of borrowings resulting from Slavic-Albanian interaction is important for understanding which communities experienced these exchanges of terminology. As with the semantic categories represented in the borrowings, different patterns emerge in borrowings from Slavic to Albanian than in those words borrowed from Albanian to Slavic. As shown here, the Slavic influence on Albanian vocabulary permeates all Albanian dialects, including the standard, whereas borrowings from Albanian into Slavic remain fairly limited to dialects where Slavic-Albanian contact is ongoing. Here, however, I should like to add the caution that standard languages are a particularly unreliable measure for evaluating borrowings, because a standard language is but one variety of a language: a privileged codified dialect whose form is determined by influential individuals or institutions. For ideological purposes, the standard variety is often shaped to appear less (or more) like another language (Browne 2002). The emerging varieties of Croatian and Bosnian-each intentionally less like Serbian - are good examples of this (Alexander 2006: 404-415), as are campaigns against Turkish vocabulary in Albanian, Greek, and other Balkan languages (Kazazis 1972). Specific to the topic at hand, more and more forms considered "Slavic" have been excluded from the Albanian standard, as shown in the standard dictionaries' $(1954,1980,1984)$ inclusion of less and less vocabulary with Slavic origins (Svane 1992: 279). Although I know of no campaign against Albanianisms in Slavic standard languages, the precaution about relying on standard languages alone is valid for these, too. As the overall influence of language contact should not be measured by the standard languages alone; data from individual dialects is of the utmost value in this and other language-contact investigations (Friedman and Joseph 2014).

One of the greatest indications of the influence of Slavic on Albanian is the geographical spread of borrowings from Slavic in Albanian dialects. Every major Albanian dialect includes several Slavic loanwords. These can be found in Geg in the north (northern Albania, Montenegro, Kosovo, southern Serbia, western Macedonia), Tosk in the south (southern Albania, southwest Macedonia, northern Greece), and the Albanian settlements from the Middle Ages in southern Italy and southern Greece: Arbëresh and Arvanitika, respectively. The common-sense opinion held by some Albanian linguists that one of the general differences between Geg and Tosk is the higher concentration of loanwords from Slavic and Turkish in Geg and the higher number of Italian and Greek loanwords in Tosk, ${ }^{10}$ is not completely accurate, as Tosk dialects within Albania have more borrowings from Slavic than do Geg dialects in Albania (Ylli 1997); and the Tosk-based standard has more than either dialect alone as schematized in Figure 4, below.

${ }^{10}$ For example as expressed in the introduction of Mëniku and Campos (2011). 


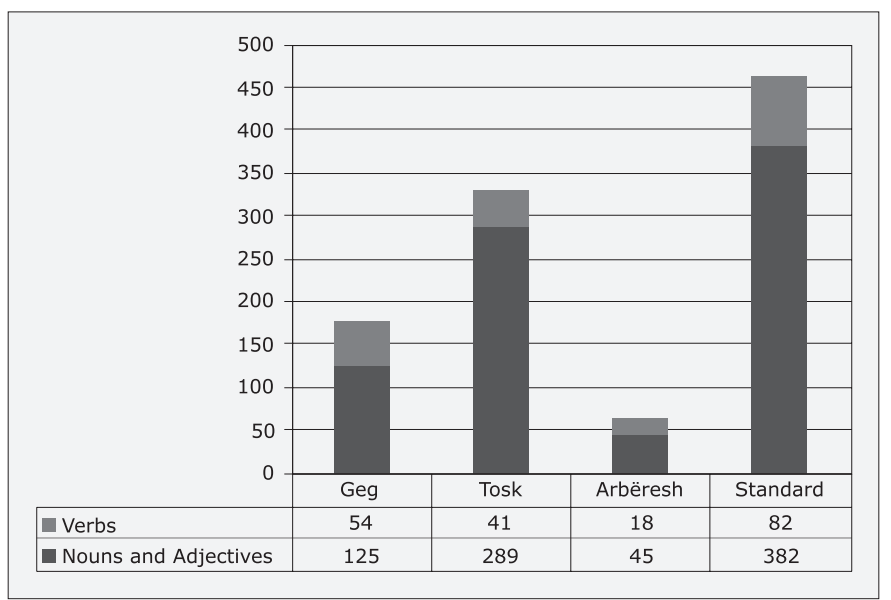

Figure 3. Slavic $\rightarrow$ Albanian Borrowings by Dialect (based on Svane 1992: 287-288)

The more accurate generalization is not based on the North-South split of Geg and Tosk, but rather on those areas that have had particularly high levels of interaction with Slavic, both in the present, such as Shkodër in the northwest and Korçë in the southeast, and in the past, as in the areas of Vlorë in the south on the west coast and in Myzeqe and Berat in central south Albania, areas where Slavic dialects are presumed to have existed since the Bulgarian Empires' conquests in the region in the $9^{\text {th }}$ century (Svane 1992; Çabej 1962/2008). This can be seen in more detail in dialect investigations conducted by Xhelal Ylli (1997) who tested where individual borrowings from Slavic are accepted. From his work it appears that the areas with the highest acceptance of forms are where Slavic populations continue: Korçë, near Macedonia in the southeast, and Shkodër, near Montenegro in the northwest. Of the 1000 or so words in Ylli's corpus, the highest number (430) are accepted in Korçë and Shkodër was second at 402. Other areas close to Slavic communities also retain many borrowings, like Tropojë (347), which is ethnographically connected with the highlands of Gjakovë/Đakovica in Kosovo, and Pogradec (316) on southern shore of Lake Ohrid. Several municipalities in south central Albania still recognize many Slavic loanwords, including Përmet (302) and Vlorë (300). Unfortunately, neither Svane (1992) nor Ylli (1997) investigate borrowings in Albanian dialects in the former Yugoslavia, but if the trend shown in Ylli (1997) continues, those dialects (all Geg except some Tosk dialects in southwestern Macedonia) likely have even more borrowings from Slavic.

Borrowings from Albanian to Slavic are also concentrated in the dialects where Slavic-Albanian contact is ongoing. However borrowings are not necessarily limited to areas where Albanians are still present. Hoxha (2001) cites examples from places as remote from Albanian communities as Slovenia and Bulgaria, and Murati (2000) claims that borrowings extend into dialects far from Albanian speaking communities in Macedonia, particularly into standard 
Macedonian. As argued above, influence should not be measured primarily on the basis of forms in contemporary standard languages, but at least as a matter of curiosity - to say nothing of the possible motivations for such borrowings - the Serbian and Macedonian forms kopile 'illegitimate son', struga 'sheepfold, pen', (Hamp 1977) and vatra 'fire, hearth' (Hamp 1976) are worth mentioning as possible loanwords from Albanian, although their origins are disputable. According to Hoxha (2001), the greatest number of borrowings are found in Slavic dialects in west and southwest Macedonia, followed by dialects in Kosovo and in Plava and Gusinje in (northwest) Montenegro and southwest Montenegro. Gora dialects in Dragaš/Sharr in southern Kosovo and Serbian dialects in southern Serbia contain somewhat fewer borrowings, whereas other South Slavic dialects contain a handful of possible borrowings from Albanian. This distribution is represented in Figure 4, below.

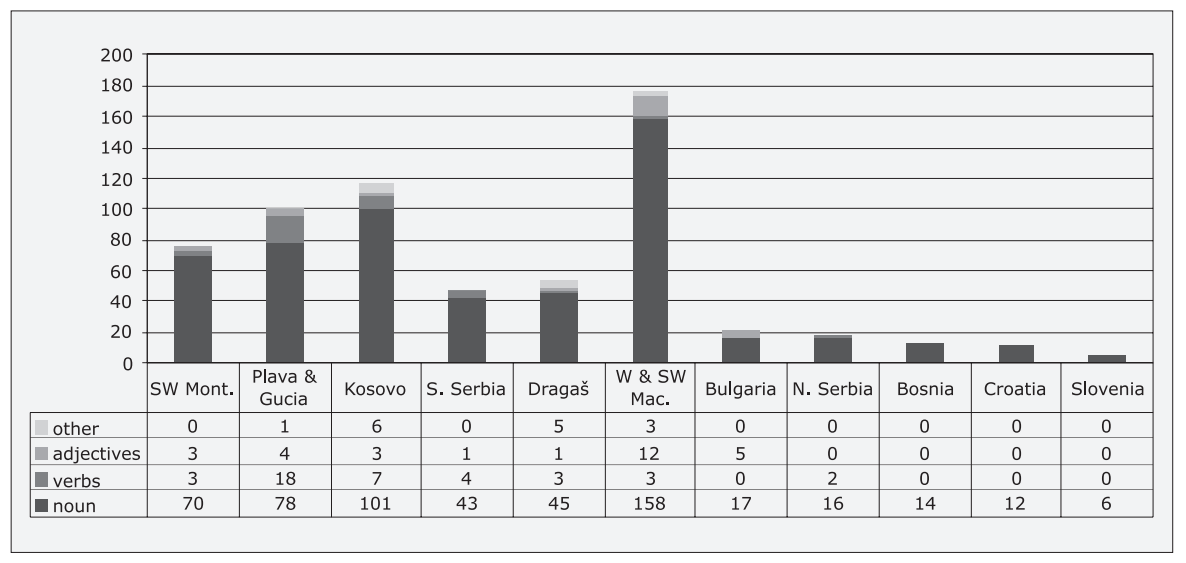

Figure 4. Number of Albanian Borrowings in South Slavic Dialects (acc. to Hoxha 2001)

\subsection{Time of Borrowings}

The main historical information relevant to the chronology of Slavic-Albanian contact are two migrations: the migrations of Slavs to the Balkans beginning in the $6^{\text {th }}$ century AD (likely coming in contact with the Pre-Albanian population somewhat later) and the migration of Arbëresh Albanians to Italy in the $15^{\text {th }}$ century. Within this timeframe, the time of Slavic-Albanian borrowings can be narrowed somewhat by the borrowings' locations. For example, borrowings

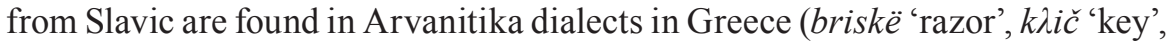
etc.) and Arbëresh in southern Italy, (bisedë 'conversation', bliznak 'twin', dubë 'oak', etc.). Since some Arvanitika settlements likely had no significant contact with Slavic since the end of the $14^{\text {th }}$ century, and Arbëresh settlements have been isolated from Slavic since the $15^{\text {th }}$ century, these words must have been borrowed before the $15^{\text {th }}$ century (Svane 1992: 291). Based on the time of the Slavs' migrations to the Balkans and borrowings in Arvanitika and Arbëresh 
dialects, most Slavic borrowings were likely borrowed between 700 and 1500 AD (Svane 1992: 290). ${ }^{11}$

Unfortunately, neither Albanian nor Slavic writing provides much direct evidence for the chronology of borrowings. The earliest Albanian literature contains several borrowings from Slavic, although it dates only from the $16^{\text {th }}$ century, with the earliest extant Albanian writing being Gjon Buzuku's Meshari (1555). Slavic borrowings like shtrazë 'guard', rob 'slave', and porosit 'order, request' are quite common in his writing and other classical Albanian works into the $17^{\text {th }}$ century. Thus, borrowings from Slavic had been incorporated some time before this. ${ }^{12}$ Slavic writing precedes Albanian writing by several centuries, beginning in the $9^{\text {th }}$ century, with the earliest existing Slavic writing from the end of the $10^{\text {th }}$ century or middle of the $11^{\text {th }}$ century (Lunt 2001: 3). However, during the Ottoman Empire the literary tradition fell off precipitously, thus direct evidence of Albanian borrowings into Slavic for this period is unavailable. Instead some scholars have looked to $19^{\text {th }}$ and $20^{\text {th }}$ century Slavic heroic folk songs (Blaku 1989/2010) and dictionaries (Ajeti 2001) for evidence of borrowings from Albanian. Still, these give a late timeframe for investigation, as these date only to the mid- $19^{\text {th }}$ century. To my knowledge, no study of preOttoman Slavic manuscripts has revealed any significant Albanian influence. Without evidence to the contrary, it may be assumed that many, and perhaps a majority, of Albanian borrowings into Slavic coincided with the Ottoman rule $\left(15^{\text {th }}-19^{\text {th }}\right.$ Centuries).

A type of indirect evidence validates this assumption - the phonological histories of Slavic and Albanian. ${ }^{13}$ Among the changes Albanian underwent during the time of contact with Slavic is $* / \mathrm{s} />/ \mathrm{sh} /[\mathrm{S}]$ (ca. $10^{\text {th }}$ cent. AD) and the development of affricate phonemes /c/ [ts] and /ç/ [t $]$, (somewhat later, ca. $11^{\text {th }}-13^{\text {th }}$ cent. AD) (Topalli, Forthcoming). Slavic $\rightarrow$ Albanian borrowings have reflexes before and after both of these changes: Alb. grusht 'fist' (cf. OCS grbstb) and Alb. bisedë 'talk, speech' (cf. Srb. beseda), the first preceding the change of $* / \mathrm{s} />/ \mathrm{sh} /$ and the second following it; so too with Alb. porosit 'to order, request' $<$ Sl. poročiti, carde 'small load, burden' $<$ Sl. čerda, and Alb. çudit 'to amaze' < Sl. *čuditi with here the first two forms show borrowings before the development of the affricate in Albanian, while the last is a borrowing after its development. Borrowings from Slavic tend to show only the later forms of Albanian, and were, thus, borrowed some time after the Albanian borrowings from Slavic: čkrepam, škrepam 'to ignite' < Alb. shkrep and džupleta 'woolen sleeveless smock' < Alb. xhubleta [dzubleta]. During this same

${ }^{11}$ This is not to say Albanian has not borrowed from Slavic more recently; many words have been borrowed from Serbian and Macedonian over the past two centuries, particularly by Albanian dialects in the former Yugoslavia.

12 There is mention of Albanian writing as early as the 1300's (Ismajli 2000, Vermeer 1992), but at present the earliest available textual evidence is from the $16^{\text {th }}$ century.

${ }^{13}$ This treatment of historical phonology is of necessity abbreviated; further consideration is given in Curtis (2012). 
time, South Slavic languages also underwent several sound changes, such as the denasalization of nasal vowels, the merger of jers with other vowels, the merger of CSl. *y with /i/, and the metathesis of vowel-resonant sequences before obstruents $((\mathrm{T}) \mathrm{ORT}>(\mathrm{T}) \mathrm{RAT})$. Slavic $\rightarrow$ Albanian borrowings show a variety of outcomes for all but the earliest of these changes, indicating that lexicon was borrowed in the same period as the sound changes. For example, nasality of CSl. nasal vowels is preserved in Alb. rendi 'order, place', < rędb, but not in Alb. opet 'again' < opętb. Albanian $\rightarrow$ Slavic borrowings, however, fairly consistently reflect later stages of Slavic. Although the precise chronology of these borrowings is unknown, and likely impossible to know certainly, the relative chronology of Slavic $\rightarrow$ Albanian borrowings to Albanian $\rightarrow$ Slavic borrowings is quite secure. In almost every case, borrowings from Albanian to Slavic appear to come from later periods than those from Slavic into Albanian as evidenced by the historical phonology. While Slavic $\rightarrow$ Albanian borrowings started early_perhaps around $700 \mathrm{AD}$ - and lasted until $1500 \mathrm{AD}$, most were borrowed in the first half of the second millennium AD (Svane 1992). On the other hand, Albanian $\rightarrow$ Slavic borrowings likely took place towards the middle and second half of the millennium, thus overlapping with the time of the Ottoman Empire (Curtis 2012: 92-126).

\section{Conclusion}

Regarding the distinction between borrowing and imposition, both Albanian and Slavic have played the role of donor and of recipient. In other words, Slavic borrowed from Albanian as well as contributed to Albanian, and vice versa. In these interactions, however, Slavic lexicon was borrowed in greater numbers, and over a wider range of territory than Albanian lexicon. Likewise, while both Slavic and Albanian communities incorporated grammatical words from the other language, the percentage of functional words in Albanian $\rightarrow$ Slavic borrowings is greater than for Slavic $\rightarrow$ Albanian borrowings, perhaps indicating that Albanian material may have been transferred to Slavic by way of L2 imposition. Thus, it is too simplistic to say that the exchange of lexicon was one-directional or that only one type of transfer was involved. When compared to the historical period of borrowings it appears that Slavic $\rightarrow$ Albanian borrowings took place when conditions favored borrowing from Slavic (medieval Slavic Empires), while Albanian $\rightarrow$ Slavic borrowings happened when Albanian was favored locally (Ottoman Empire).

Second, according to Thomason and Kaufman's approach, the presence of grammatical words suggests fairly intense contact between Slavic and Albanian. Function words taken from Albanian to Slavic dialects include the adverb kret 'entirely' (cf. Alb. krejt), the preposition: pr 'for' (cf. Alb. për), the pronoun and interjection koč 'so much' (cf. Alb. kaq), as well as the interjection ja! '(look) here!' and the conjunction 'se 'that' (Hoxha 2001). Only one derivational morpheme has been taken into Slavic (the diminutive suffix -zë used in some 
Montenegrin toponyms and names like Sukeza (Stanišić 1995: 56). Borrowings from Slavic to Albanian, however, include several derivational morphemes in addition to the handful of functional words. These include adverbs opet 'again' and okoll 'around' (cf. Srb. okolo) and the conjunction radi se 'because'; derivational suffixes from Slavic are used productively and not just with Slavic stems, eg. the suffix -ishte used for locations, as in ranishte 'sandy pit' (cf. Geg ranë 'sand' + -ishte), the feminizing suffix -ka: yllka 'star' (fem., also a proper name) (cf. Alb. $y l l$ 'star (masc.)'), along with the suffixes -ash, -icë, -inë, -nik, and -ec (Svane 1992: 290). On the basis of these many derivational suffixes, it appears that the language contact for borrowings from Slavic to Albanian appears to have been somewhat more intense than Albanian $\rightarrow$ Slavic borrowings. By implication Albanian communities likely had more cultural pressure to learn Slavic than Slavic communities had to learn Albanian.

Finally, borrowings from both directions include some ERIC loans like the grammatical words discussed above as well as kinship terms. These types of borrowings further indicate periods of fairly intense cultural contact. However, this claim should be put into perspective somewhat by comparing ERIC loans in other cases of language contact in the Balkans. Although Friedman and Joseph do not quantify ERIC loans in the Balkan languages, it seems that these are more frequent in Albanian or Balkan Slavic interactions with other languages such as Greek, Aromanian, and Turkish than with one another. Thus, it may be that Slavic-Albanian language contact is on a smaller scale than other language-contact interactions in the Balkans.

Returning to the implications for socio-historical relations that the evidence from lexical borrowing presents, contact between Slavic and Albanian has produced changes to dialects in both language families over the long period of cultural interaction. The influence from Slavic to Albanian has been more extensive geographically and numerically, but Albanian has contributed many words to neighboring Slavic dialects as well. ERIC loans, in particular, indicate times of intense contact - presumably on fair or neutral terms - although the smaller number of changes compared to other contact situations in the Balkans may indicate that at other times, there may have also been ideological or practical motivations not to borrow from one language or the other.

\section{REFERENCES}

Idriz AJETI, 2001: Vepra IV. Prishtinë: Akademia e Shkencëve dhe e Artëve të Kosovës.

Ronelle ALEXANDER, 2006: Bosnian, Croatian, Serbian, a Grammar: With Sociolinguistic Commentary. Madison, Wisconsin: University of Wisconsin Press.

Murat BLAKU, 1989/2010: Ndikimi i shqipes mbi të folmet serbe të Kosovës: Sipas materialeve gjuhësore të botuara. Ph.D. dissertation, University in Prishtina. Prishtinë: Institut Albanologjik i Prishtinës. 
Leonard BLOOMFIELD, 1933: Language. New York: Henry Holt and Co.

Wayles BROWNE, 2002: What is a standard language good for, and who gets to have one? Columbus, Ohio: Department of Slavic and East European Languages and Literatures, The Ohio State University. (The Kenneth E. Naylor Memorial Lecture Series in South Slavic Linguistics, 3).

Matthew CURTIS, 2007: Petar II Petrović Njegoš and Gjergj Fishta: Composers of National Epics. Pittsburgh: University of Pittsburgh Press. (The Carl Beck Papers in Russian and East European Studies, 1808). 16-20.

- -, 2012: Slavic-Albanian Language Contact, Convergence, and Coexistence. PhD. Dissertation, The Ohio State University, Department of Slavic and East European Languages, Literatures, and Cultures.

Eqrem ÇABEJ, 1962/2008: Hyrje në historinë e gjuhës shqipe. Tiranë: Çabej.

Victor A. FRIEDMAN and Brian D. JOSEPH (forthcoming): Lessons from Judezmo about the Balkan Sprachbund and Contact Linguistics. To appear in International Journal of the Sociology of Language, Special Issue ed. by Ghil'ad Zuckerman.

- -, (forthcoming): The Balkan languages. Cambridge: Cambridge University Press.

Eric HAMP, 1970: Early Slavic Influence on Albanian. Balkansko ezikoznanie 14/2, $11-17$.

- -, 1976: On the distribution and origin of vatra. Opuscula slavica et linguistica: Festschrift für Alexander Issastchenko. Klagenfurt: Heyn. (Schriftenreihe Sprachwissenschaft, Bd. 1). 201-210.

--, 1977: Strunga. Balkansko ezikoznanie 20/1-2, 113-117.

Safet HOXHA, 2001: Elemente leksikore të gjuhës shqipe në gjuhët sllave ballkanike. Shkodër: Camaj-Pipa.

Martin HULD, 1983: Basic Albanian Etymologies. Columbus, OH: Slavica.

Rexhep ISMAJLI, 2000: Tekste të vjetra. Pejë: Dukagjini.

Brian D. JOSEPH, 2010: Labeling Loanword Types in the Balkans. Paper presented at 17th Balkan and South Slavic Conference on Language, Linguistics, and Folklore. The Ohio State University, Columbus April 15, 2010.

Kostas KAZAZIS, 1972: The Status of Turkisms in the Present-Day Balkan Languages. Aspects of the Balkans: Continuity and Change. Eds. Henrik Birnbaum and Speros Vryonis, Jr. The Hague: Mouton. (Slavistic Printings and Reprintings, 270). 87-116.

Androkli KOSTALLARI, Jani THOMAJ, Xhevat LlOSHI, Miço SAMARA, 1980: Fjalor i gjuhës së sotme shqipe. Tiranë: Akademia e Shkencave e RPS te Shqiperise, Instituti i Gjuhesise dhe i Letersise.

Horace LUNT, 2001: Old Church Slavonic Grammar. $7^{\text {th }}$ edition. The Hague: Mouton.

Linda MËNIKU and Hector CAMPOS, 2011: Discovering Albanian 1 Textbook. Madison, WI: University of Wisconsin Press.

Qemal MURATI, 2007: Bashkëmarrëdhëniet gjuhësore shqiptare-maqedonase Меѓусебни албанскомакедонски јазични влијанија - Albanian-Macedonian Language Interrelations. Tetovo: State University of Tetovo. 
Leonard NEWMARK, 1998: Albanian-English Dictionary. Oxford: Oxford University Press.

Vanja STANIŠIĆ, 1995: Srpsko-albanski jezični odnosi. Beograd: Srpska akademija nauka i umetnosti, Balkanološki institute. (Posebna izdanja, 59).

Gunnar SVANE, 1992: Slavische Lehnwörter im Albanischen. Aarhus: Aarhus University Press. (Acta Jutlandica LXVIII, Humanistische Reihe, 67).

Jani THOMAJ et al., 2006: Fjalor i Gjuhës Shqipe. Tiranë: Akademia e Shkencave e Shqipërisë, Instituti i Gjuhësisë dhe i Letërsisë.

Sarah THOMASON and Terrence KAUFMAN, 1988: Language Contact, Creolization, and Genetic Linguistics. Berkeley: University of California.

Albert THUMB, 1910: Altgriechische Elemente des Albanesischen. Indogermanische Forschungen 26, 1-20.

Kolec TOPALLI, 2007: Fonetika historike e gjuhës shqipe. Tirana: Shtëpia Botuese Dituria. [English edition forthcoming: Kolec Topalli, Phonological History of Albanian.] 359.

Frans VAN COETSEM, 1988/2000: Loan Phonology and The Two Transfer Types in Language Contact. Dordrecht, Holland: Foris Publications.

Willem VERMEER, 1992: Albanians and Serbs in Yugoslavia. Yearbook of European Studies / Annuaire d'Études Européennes 5, 101-124.

Xhelal YLLI, 1997: Das slavische Lehngut im Albanischen. München: Otto Sagner.

\section{SLOVANSKO-ALBANSKI JEZIKOVNI STIK: BESEDJE}

Avtor prispevka na podlagi različnih pristopov k preučevanju prevzetih besed obravnava zgodovinske povezave med slovanskimi jeziki in albanščino. Ugotavlja, da so imeli vsi obravnavani jeziki vlogo darovalca in prejemnika: slovanski jeziki so si besedje izposojali iz albanščine in hkrati prispevali svoje besedje v albanski jezik ter obratno. Slovansko besedje pa je bilo vendarle izposojeno $\mathrm{v}$ večji meri in na širšem geografskem območju kot albansko. Albanščina je prispevala predvsem besedje sorodstvenih vezi in drugih kategorij, ki so bile izposojene kot posledica intenzivnega in dolgotrajnega jezikovnega stika. Ta stik predpostavlja bogato in raznoliko povezanost, ki se je razvila pod vplivom različnih okoliščin, tudi v obdobju, ko so jeziki mirno soobstajali. 